\title{
KAJIAN COD DAN BOD DALAM AIR DI LINGKUNGAN TEMPAT PEMROSESAN AKHIR (TPA) SAMPAH KALIORI KABUPATEN BANYUMAS
}

\author{
Sri Royani ${ }^{1}$, Adita Silvia Fitriana ${ }^{1)}$, Afresa Bias Putri Enarga' ${ }^{1)}$, Hanif Zufrialdi \\ Bagaskara ${ }^{1)}$ \\ ${ }^{1)}$ Program Studi Kimia, Universitas Harapan Bangsa, Banyumas \\ E-mail: sriroyani@uhb.ac.id
}

\begin{abstract}
Abstrak
Tempat Pemrosesan Akhir (TPA) sampah Kaliori Banyumas merupakan TPA non aktif yang masih terdapat timbunan sampah dan air lindi di lokasinya. Untuk mengetahui kualitas air di lingkungan tersebut, maka telah dilakukan penelitian untuk mengkaji polutan organik Biochemical Oxygen Demand (BOD) dan Chemical Oxygen Demand (COD) dalam air lindi, air sumur dan air sungai. Penentuan kadar BOD dan COD ditentukan masingmasing sesuai metode SNI 6989.72:2009 dan SNI 6989.15:2019. Berdasakan hasil pengujian, kadar COD air lindi melebihi baku mutu berdasarkan Peraturan Menteri Lingkungan Hidup dan Kehutanan RI No. P59/Menlhk/Setjen/kum.1/7/2016, dan kadar BOD masih berada di bawah ambang batas maksimal yang ditetapkan. Sedangkan untuk air sumur, hanya air sumur dengan kode SUM3 dan SUM5 yang memenuhi kualitas air kelas pertama dilihat dari parameter BOD dan COD berdasarkan Peraturan Pemerintah RI No.82 Tahun 2001, dan masih diperbolehkan sebagai air baku untuk air minum. Selain itu, air sumur dengan kode SUM2, SUM3, SUM4 dan SUM5 masih aman jika digunakan untuk prasarana mandi, cuci dan kakus karena memenuhi nilai baku mutu air kelas kedua. Nilai BOD dan COD dalam air sungai tidak memenuhi kualitas air yang bagus, baik kelas satu, dua, tiga maupun kelas empat berdasarkan Peraturan Pemerintah RI No.82 Tahun 2001. Rasio BOD/COD yang diperoleh sebesar 0,9 memungkinkan untuk dilakukan biodegradasi guna menghasilkan air yang lebih baik kualitasnya.
\end{abstract}

Kata kunci: Air Lindi, Air Sumur, Air Sungai, BOD, COD

\begin{abstract}
Kaliori Landfill in Banyumas is an inactive landfill that still has a lot of garbage and leachate in its place. To determine the quality of water in the environment, the research has been carried out to assess the organic pollutants of Biochemical Oxygen Demand (BOD) and Chemical Oxygen Demand (COD) in leachate, ground water and river water. The BOD and COD levels was determined according to the SNI 6989.72:2009 and SNI 6989.15:2019. The result showed that the COD content of leachate water was not complied the quality standard according to the Regulation of the Minister of Environment and Forestry of the Republic of Indonesia No. P59/Menlhk/Setjen/kum.1/7/2016, while the BOD level was complied the quality standard. Meanwhile, only ground water of SUM3 and SUM5 which have good agreement with quality standard of water in the first class according to Government Regulation No.82/2001, so it is still allowed as raw water for drinking. In addition, ground water of SUM2, SUM3, SUM4 and SUM5 is still safe if it is use for sanitation infrastructure because it has a good agreement with the second class water quality standard. The values of BOD and COD in river water do not have good water quality, either first class or fourth class according to the Government Regulation No.82/2001. The obtained BOD/COD ratio is 0.9 , and it allows to biodegradation to produce the better quality of water.
\end{abstract}

Key words: BOD, COD, Ground Water, Leachate, River Water 


\section{PENDAHULUAN}

Sampah merupakan permasalahan yang tidak ada habisnya di dunia, tidak terkecuali di Indonesia. Beberapa tahun terakhir ini, Tempat Pemrosesan Akhir sampah (TPA) dijadikan sebagai salah satu tempat akhir untuk membuang sampah oleh kebanyakan masyarakat di Indonesia. Air lindi, yang merupakan air limbah yang dihasilkan TPA, sering dianggap sebagai sumber kontaminan air tanah dan air sungai di sekitarnya.

TPA Kaliori merupakan salah satu TPA di Banyumas. TPA ini merupakan TPA yang sudah tidak aktif lagi, namun masih terdapat timbunan sampah dan kolam air lindi di lokasi tersebut. Timbunan sampah dan air lindi ini dikahawatirkan berdampak buruk terhadap kualitas air di lingkungan sekitar. Beberapa penelitian menyatakan bahwa air lindi dapat mempengaruhi kualitas air di sekitar TPA (Ling and Zhang, 2017; Pande et al., 2015). Selain itu, air lindi dinyatakan sebagai sumber utama polusi pada air tanah dan air permukaan. Sekarang ini, pengaruh air lindi pada sumber air menjadi perhatian utama karena dampaknya terhadap lingkungan yang sangat signifikan. Sebagai contoh air lindi dengan kualitas buruk menyebabkan eksosistem badan air di sekitarnya menjadi ikut tercemar (Akinbile, 2012; Klinck and Stuart, 1999).

Menurut Koda et al (2017), kandungan air lindi terdiri dari zat organik, zat anorganik dan logam berat. Parameter Chemical Oxygen Demand (COD) dan Biochemical Oxygen Demand (BOD) sering digunakan untuk mengetahui kandungan zat organik dalam air. COD dan BOD adalah dua diantara parameter kualitas air di Indonesia berdasarkan Peraturan Pemerintah Republik Indonesia No.82 Tahun 2001 (PP RI No.82 Th.2001). Pada umumnya, kandungan COD dan BOD dalam air dikaji untuk yang menggambarkan banyaknya zat organik yang terlarut dalam air tersebut. COD merupakan kebutuhan oksigen kimia untuk mengurai seluruh bahan organic yang terkandung dalam air. BOD merupakan jumlah oksigen terlarut yang dibutuhkan oleh bakteri untuk menguraikan (mengoksidasi) hampir semua zat organik yang terlarut dan sebagian zat organik yang tersuspensi dalam air. Koda et al (2017) dalam penelitiannya menyatakan bahwa COD dan BOD merupakan indikator untuk menentukan kualitas air lindi.

Maksud dari artikel ini adalah untuk mengkaji kualitas air di lingkungan TPA Kaliori Banyumas dilihat dari parameter material organik yaitu COD dan BOD. Air yang dikaji yaitu air lindi, air sumur warga dan air sungai. Penelitian ini merupakan penelitian rintisan untuk mengetahui kualitas air di lingkungan TPA non aktif di Kaliori, Banyumas. 


\section{METODE PENELITIAN}

Penelitian ini merupakan sebuah sebuah penelitian deskriptif eksperimental. Sampel yang diteliti antara lain air lindi, air sumur dan air sungai di lingkungan sekitar TPA sampah Kaliori Kabupaten Banyumas dengan radius kurang dari satu kilometer. Pengambilan sampel dengan radius tersebut dilakukan karena pemukiman penduduk terdekat berjarak kurang dari satu kilometer dari lokasi TPA, sehingga perlu dilakukan penelitian terhadap kualitas air di lingkungan tersebut. Pengambilan sampel dilakukan pada bulan Mei 2020. Terdapat 1 titik air lindi, 5 titik air sumur dan 2 titik air sungai yang telah dikumpulkan. Lokasi pengambilan sampel air sumur dan air sungai didasarkan pada jaraknya terhadap air lindi di TPA. Identitas sampel yang digunakan dapat dilihat pada Tabel 1, sedangkan lokasi pengambilan sampel dapat dilihat pada Gambar 1.

Tabel 1. Kode dan Identitas Sampel

\begin{tabular}{ccc}
\hline No. & Kode Sampel & Identitas Sampel \\
\hline 1 & LIN & Air lindi \\
\hline 2 & AS 1 & Air sungai jarak terdekat pertama dengan TPA \\
\hline 3 & AS 2 & Air sungai jarak terdekat kedua dengan TPA \\
\hline 4 & SUM 1 & Air sumur warga jarak terdekat pertama dengan TPA \\
\hline 5 & SUM 2 & Air sumur warga jarak terdekat kedua dengan TPA \\
\hline 6 & SUM 3 & Air sumur warga jarak terdekat ketiga dengan TPA \\
\hline 7 & SUM 4 & Air sumur warga jarak terdekat keempat dengan TPA \\
\hline 8 & SUM 5 & Air sumur warga jarak terdekat kelima dengan TPA \\
\hline
\end{tabular}

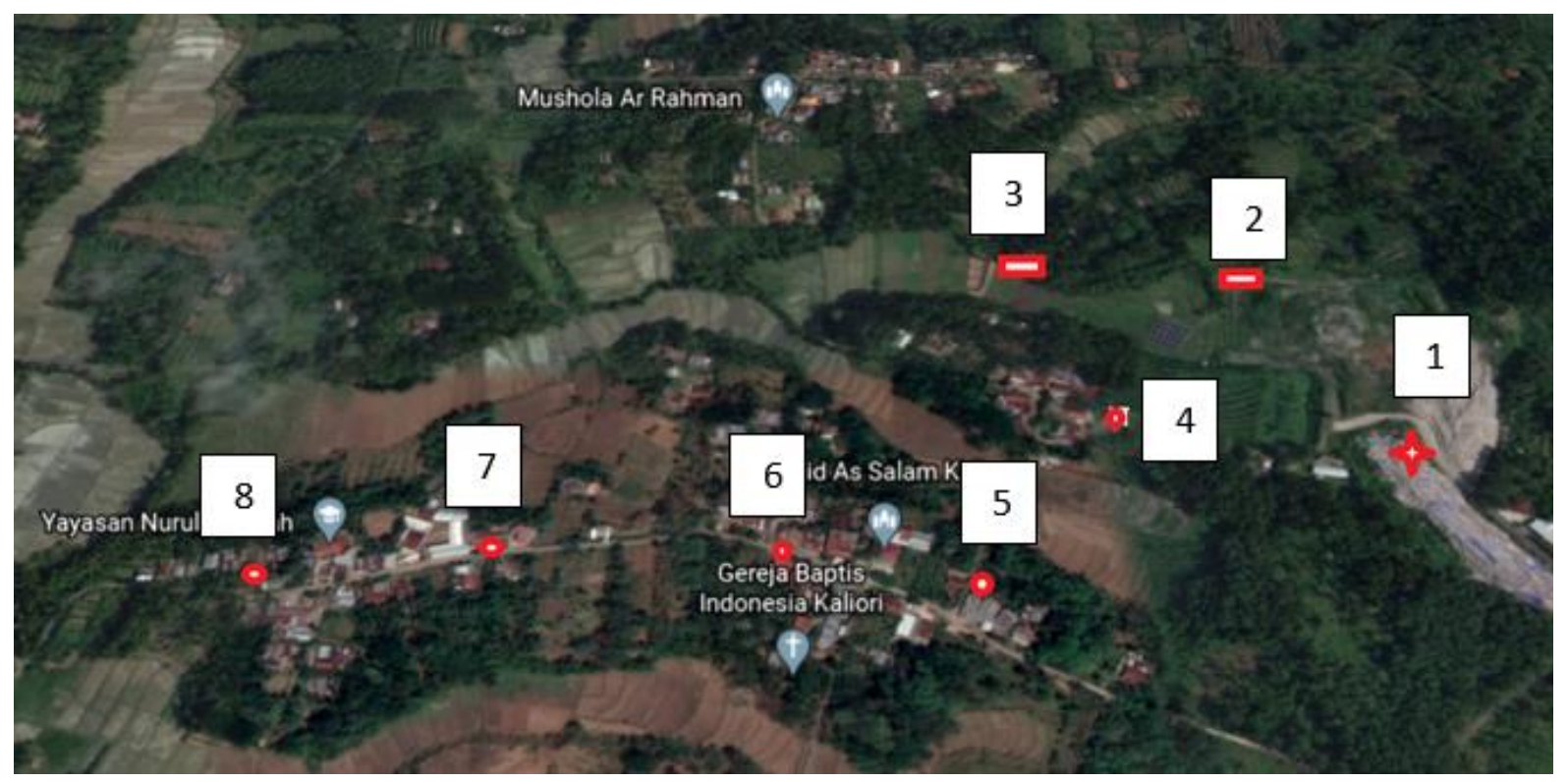

Gambar 1. Lokasi Pengambilan Sampel, TPA Kaliori Banyumas 
Penentuan kadar BOD dan COD ditentukan masing-masing sesuai metode SNI 6989.72:2009 tentang cara uji Kebutuhan Oksigen Biokimia (Biochemical Oxygen Demand/BOD) dan SNI 6989.15:2019 tentang cara uji Kebutuhan Oksigen Kimiawi (Chemical Oxygen Demand/COD) (BSN, 2019). Kadar yang diperoleh kemudian dibandingkan dengan baku mutu standar nasional, yaitu Peraturan Menteri Lingkungan Hidup dan Kehutanan RI No. P59/Menlhk/Setjen/kum.1/7/2016 dan Peraturan Pemerintah RI No.82 Tahun 2001.

\section{HASIL DAN PEMBAHASAN}

\subsection{BOD dan COD Air Lindi}

Air lindi TPA Kaliori menunjukan warna coklat pekat dan bau yang busuk dan menyengat. Tabel 2.menunjukan karakteristik air lindi TPA Kaliori berdasarkan dari parameter BOD dan COD.

Tabel 2. BOD dan COD Air Lindi

\begin{tabular}{ccc}
\hline Parameter & Kadar $(\mathbf{m g} / \mathbf{L})$ & Baku mutu $(\mathbf{m g} / \mathbf{L}) *)$ \\
\hline BOD & 146,09 & 150,00 \\
\hline COD & 568,48 & 300,00 \\
\hline
\end{tabular}

*) baku mutu Peraturan Menteri Lingkungan Hidup dan Kehutanan RI No. P59/Menlhk/Setjen/kum.1/7/2016

Berdasarkan Tabel 2, Kadar kedua parameter dalam air lindi tersebut sangat tinggi, dengan kadar COD lebih tinggi dibandingkan kadar BOD. Kadar BOD dan COD masing-masing yaitu 146,09 mg/L dan 568,48 mg/L. Hal ini menunjukan bahwa banyaknya senyawa organik dalam air tersebut. Nilai COD selalu lebih tinggi dibandingkan BOD, hal ini karena banyak zat organik yang dioksidasi secara kimiawi tetapi tidak dapat dioksidasi secara biologis (Khan et al., 2011). Hasil serupa diperoleh oleh Sari dan Afdal (2017) yang menyatakan bahwa kadar COD lebih tinggi dibandingkan BOD.

Kadar BOD yang diperoleh masih berada di bawah kadar yang ditetapkan oleh pemerintah, yaitu sebesar $150 \mathrm{mg} / \mathrm{L}$ untuk air lindi berdasarkan Peraturan Menteri Lingkungan Hidup dan Kehutanan RI No. P59/Menlhk/Setjen/kum.1/7/2016. Lain halnya dengan BOD, nilai COD diperoleh berada di atas nilai ambang batas yang ditetapkan oleh pemerintah, yaitu sebesar 300 mg/L. Nilai COD dan BOD yang tinggi menandakan kekuatan senyawa organic pada air lindi tersebut. Oleh karena itu, air lindi perlu diproses terlebih dahulu supaya tidak menimbulkan pencemaran terhadap air di lingkungan TPA. 


\subsection{BOD dan COD Air Sumur}

Kadar BOD dan COD yang dihasilkan dari air sumur di lingkungan sekitar TPA berada pada rentang konsentrasi masing-masing 0,86-1,91 $\mathrm{mg} / \mathrm{L}$ dan 7,97-57,36 $\mathrm{mg} / \mathrm{L}$, seperti yang disajikan pada Gambar 2. Kadar BOD dan COD dengan rentang masing-masing 0,86-1,91 $\mathrm{mg} / \mathrm{L}$ dan 7,97-57,36 mg/L menandakan bahwa sedikit sekali kontaminan organik dari air lindi yang mencemari air sumur di lingkungan ini. Kadar tertinggi BOD dan COD masing-masing dimiliki oleh sampel dengan kode SUM1, yang diambil dari titik sampling pertama yang mempunyai jarak terdekat dengan kolam air lindi. Tingginya kadar BOD dan COD pada sampel tersebut dikarenakan jaraknya yang dekat dengan air lindi yang mempunyai kadar BOD dan COD sangat tinggi (Tabel 2). Jarak yang dekat dengan sumber polutan bisa mengakibatkan sumber air menjadi tercemar.

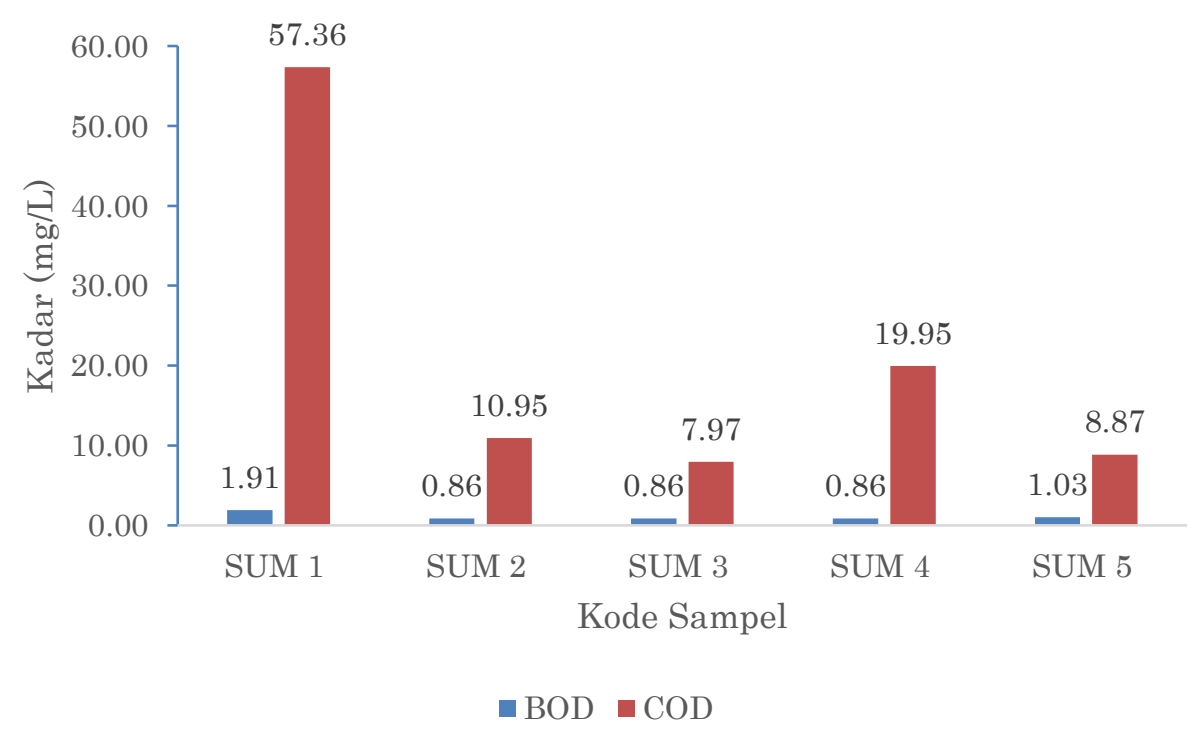

Gambar 2. BOD dan COD air sumur

Di Indonesia, belum ada standar yang menyebutkan nilai ambang batas BOD dan COD dalam air sumur atau air tanah. Akan tetapi, masyarakat Indonesia biasa menggunakan air sumur sebagai air untuk mandi, cuci dan kakus, bahkan sebagian ada yang menjadikan air sumur sebagai air baku untuk air minum. Jika melihat dari kebiasaan ini, terdapat aturan terkait kualitas air yang diperuntukan untuk aktivitas tersebut, yaitu Peraturan Pemerintah RI No.82 Tahun 2001 yang menggolongkan air ke dalam beberapa kelas. Kelas pertama diperuntukan bagi air baku untuk air minum. Jika dilihat dari rentang nilai BOD dan COD yang diperoleh, sangat jelas bahwa mayoritas kadar BOD dan COD yang diperoleh melebihi nilai baku mutu 
air kelas pertama yaitu $2 \mathrm{mg} / \mathrm{L}$ BOD dan $10 \mathrm{mg} / \mathrm{L}$ COD. Hanya air sumur dengan kode SUM3 dan SUM5 yang memenuhi kualitas air kelas pertama, sehingga diperbolehkan sebagai air baku untuk air minum.

Air kelas kedua diperuntukan bagi prasarana seperti mandi, cuci dan kakus (PP RI No.82 Th.2001). Baku mutu air kelas kedua yaitu sebesar 3 mg/L BOD dan 25 mg/L COD. Dari kelima air sumur, hanya air sumur dengan kode SUM1 yang melebihi nilai baku mutu kelas dua, sehingga air sumur dengan kode SUM2-SUM5 masih aman jika digunakan untuk prasarana mandi, cuci dan kakus. Dari penjelasan ini dapat dikatakan bahwa air sumur dengan kode SUM1, dimana letaknya sangat dekat dengan air lindi, tidak memenuhi kualitas air yang diperuntukan untuk air minum dan prasarana mandi cuci kakus.

\subsection{BOD dan COD Air Sungai}

Air sungai merupakan air yang banyak dimanfaatkan oleh masyarakat Indonesia untuk mengairi kebun dan kolam. Jika dilihat dari kebiasaan ini, air yang dimaksud termasuk ke dalam air kelas empat sesuai Peraturan Pemerintah RI No.82 Tahun 2001. Karaktersitik COD dan BOD air sungai dapat dilihat pada Tabel 3.

Tabel 3. BOD dan COD air sungai

\begin{tabular}{ccccccc}
\hline & \multicolumn{2}{c}{ Kadar sampel (mg/L) } & \multicolumn{4}{c}{ Kadar baku mutu air (mg/L) *) } \\
\cline { 2 - 7 } & AS 1 & AS 2 & Kelas 1 & Kelas 2 & Kelas 3 & Kelas 4 \\
\hline BOD & 56,1 & 54,6 & 2 & 3 & 6 & 12 \\
\hline COD & 173,89 & 207,33 & 10 & 25 & 50 & 100 \\
\hline
\end{tabular}

*) Peraturan Pemerintah RI No.82 Tahun 2001

Berdasarkan Tabel 3., kadar BOD dan COD dalam air sungai melebihi nilai baku mutu untuk air kelas 1 - 4 berdasarkan Peraturan Pemerintah RI No.82 Tahun 2001, yaitu 2 mg/L BOD dan $10 \mathrm{mg} / \mathrm{L}$ COD untuk air kelas 1; $3 \mathrm{mg} / \mathrm{L}$ BOD dan $25 \mathrm{mg} / \mathrm{L}$ COD untuk air kelas 2; $6 \mathrm{mg} / \mathrm{L}$ BOD dan 50 mg/L COD untuk air kelas 3; dan 12 mg/L BOD dan 100 mg/L COD untuk air kelas 4. Berdasarkan peraturan tersebut, air kelas satu diperuntukan untuk air baku air minum, kelas dua untuk prasarana/sarana rekreasi air, kelas tiga untuk budidaya ikan air tawar dan kelas 4 diperuntukan untuk mengairi pertanaman. Dengan demikian, air sungai di sekitar TPA yang telah diuji ini tidak memenuhi kualitas air yang bagus, baik kelas satu, maupun kelas empat.

Tingginya kandungan BOD dalam air sungai bisa dipengaruhi oleh jumlah mikroorganisme yang sedikit. Jumlah dan aktivitas mikroorganisme mempunyai pengaruh yang signifikan 
terhadap nilai BOD (Koda et al., 2017). Ketika jumlah mikroorgansime sedikit, proses pemecahan secara biokimia tidak terjadi atau intensitas pemecahan secara biokimia tidak signifikan. Pada kondisi natural, efek ini selalu diakibatkan oleh sejumlah komponen toksik (seperti logam berat) yang berdampak buruk terhadap aktivitas enzim mikroorganisme (Koda et al., 2017).

\subsection{Rasio Perbandingan BOD/COD}

Karakteristik air yang berada di lingkungan TPA menunjukan bahwa kadar COD lebih tinggi daripada kadar BOD, yang mana rasio BOD/COD adalah factor kunci untuk memahami kecepatan biodegradabilitas material organic dalam air (Lee and Hamid, 2014). Rasio perbandingan BOD/COD disajikan pada Gambar 3.

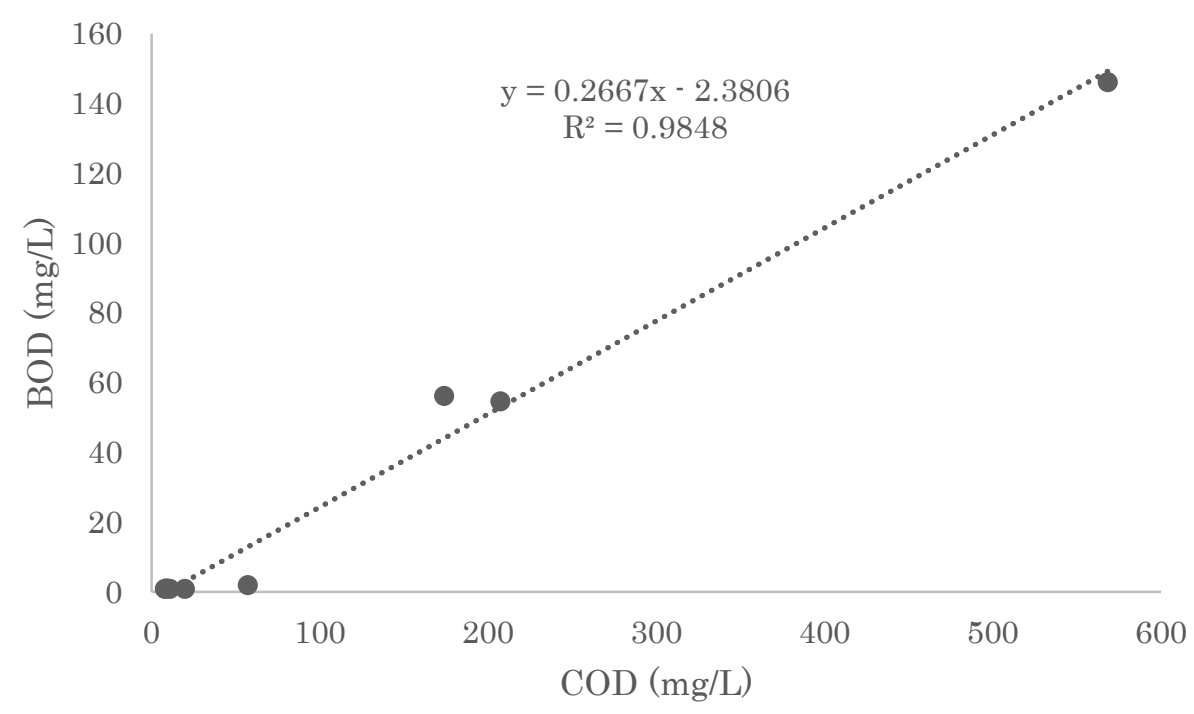

Gambar 3. Rasio perbandingan BOD dan COD.

Berdasarkan Gambar 3, diperoleh nilai $\mathrm{R} 2=0,9848$, yang artinya rasio BOD/COD adalah sebesar 0,9. Nilai tersebut menunjukan adanya korelasi kuat dan signifikan antara konsentrasi BOD dengan COD. Rasio BOD/COD berkaitan dengan nilai indikator dari degradasi material organic pada TPA. Rasio BOD/COD yang diperoleh hampir mendekati nilai 1,0, ini menunjukan bahwa material organic dalam air di lingkungan TPA mudah untuk dilakukan biodegradasi dan dapat diperlakukan secara biologis (Fullazaky, 2013). Selain itu, dapat dikatakan pula bahwa hampir tidak adanya zat organic toksik yang menghambat aktivitas mikroba (Mangkoedihardjo, 2006). Pernyataan serupa dinyatakan oleh Samudro and 
Mangkoedihardjo (2010), yang menyebutkan bahwa rasio BOD/COD antara 0,1-1,0 termasuk kelompok zona biodegradable.

Nilai COD mengindikasikan kandungan total zat organic, baik yang biodegradable maupun non-biodegradable, sedangkan nilai BOD hanya mengukur bagian biodegradable saja (Koda et al., 2017). Dengan diketahuinya rasio BOD/COD, secara tidak langsung dapat diketahui apakah zat organik tersebut biodegradable atau tidak.

Rasio ini juga dapat menunjukan tingginya kandungan polutan yang dimiliki oleh air. Rasio BOD/COD dengan nilai 0,9 dapat dikatakan memiliki kandungan polutan yang cukup tinggi. Hal ini sesuai dengan pernyataan Ngang and Abgazue (2016) yang menyatakan bahwa jika rasio BOD:COD dalam air adalah lebih tinggi atau sama dengan 0,8, maka air tersebut dapat dikatakan tinggi akan polusi. Meskipun demikian, dengan rasio yang diperoleh pada penelitian ini memungkinkan untuk diolah secara biodegradasi supaya tidak mencemari air di lingkungan sekitar.

\section{KESIMPULAN}

Berdasakan hasil pengujian, kadar COD air lindi melebihi baku mutu berdasarkan Peraturan Menteri Lingkungan Hidup dan Kehutanan RI No. P59/Menlhk/Setjen/kum.1/7/2016, sedangkan kadar BOD masih berada di bawah ambang batas maksimal yang ditetapkan. Sedangkan pada air sumur, hanya air sumur dengan kode SUM3 dan SUM5 yang memenuhi kualitas air kelas pertama dilihat dari parameter BOD dan COD berdasarkan Peraturan Pemerintah RI No.82 Tahun 2001, sehingga diperbolehkan sebagai air baku untuk air minum. Selain itu, air sumur dengan kode SUM2, SUM3, SUM4 dan SUM5 masih aman jika digunakan untuk prasarana mandi, cuci dan kakus karena memenuhi nilai baku mutu air kelas kedua. Nilai BOD dan COD dalam air sungai pada kedua titik pengambilan sampel tidak memenuhi kualitas air yang bagus, baik kelas satu, maupun kelas empat. Meskipun demikian, dengan rasio BOD/COD yang diperoleh sebesar 0,9 memungkinkan untuk dilakukan biodegradasi untuk menghasilkan air yang lebih baik kualitasnya.

\section{UCAPAN TERIMA KASIH}

Penelitian ini didanai oleh Direktorat Riset dan Pengabdian Masyarakat (DRPM) Kementerian Riset dan Teknologi / Badan Riset dan Inovasi Nasional (Kemenristek-BRIN) Tahun Anggaran 2020. 


\section{DAFTAR PUSTAKA}

Akinbile, C.O. (2012). Environmental Impact of Landfill on Groundwater Quality and Agricultural Soils in Nigeria. Soil and Water Research, 7(1): 18-26.

Badan Standardisasi Nasional. (2009). SNI 6989.72:2009: Cara uji Kebutuhan Oksigen Biokimia (Biochemical Oxygen Demand/BOD). Jakarta : BSN.

Badan Standardisasi Nasional (BSN). (2019). SNI 6989.15:2019: Cara uji Kebutuhan Oksigen Kimiawi (Chemical Oxygen Demand/COD). Jakarta : BSN.

Fullazzaky, M.A. (2013). Measurement of Biochemical Oxygen Demand of the Leachates. Environmental Monitoring and Assessment, 185: 4721-4734.

Khan, A.M., Ataullah., Shaheen, A., Ahmad, I., Malik, F and Shahid, H.A. (2011). Correlation of COD and BOD of DomesticWastewater with the power output of bioreactor. JournalChemical Society Pakistan, 33(2): 269-274.

Klinck, B and Stuart, M. (1999). Human Health Risk in Relation to Landfill Leachate Quality. Technical Report WC/99/17, British Geological Survey, Nottingham, UK.

Koda, E., Miszkowska, A., and Sieczka, A. (2017). Levels of Organic Pollution Indicators in Groundwater at the Old Landfill and Waste management Site. Applied Sciences, 7(6): 122.

Lee, A.H and Hamid, N. (2014). BOD/COD Ratio as An Indicator for Pollutants Leaching from Landfill. Journal of Clean Energy Technologies, 2(3): 263-266.

Ling, C and Zhang, Q. (2017). Evaluation of Surface Water and Groundwater Contamination in A MSW Landfill Area Using Hydrochemical Analysis and Electrical Resistivity Tomography: A Case Study in Sichuan Province, Southwest China. Environmental Monitoring and Assessment, 189(4): 1-18.

Mangkoedihardjo, S. (2006). Revaluation of Maturity and Stability Indices for Compost. Journal of Applied Sciences and Environmental Management, 10(3): 83-85.

Ngang, B.U and Agbazue, V.E. (2016). Aseasonal Assessment of Groundwater Pollution due to Biochemical Oxygen Demand, Chemical Oxygen Demand and Elevated Temperatures in Enugu Northern Senatorial District, South East Nigeria. IOSR Journal of Applied Chemitry, 9(7): 66-73.

Pande, G., Sinha, A., and Agarwal, S. (2015). Impacts of Leachate Percolation on Ground Water Quality: A Case Study of Dhanbad City. Global Nest Journal, 17(1): 162-174. 
Peraturan Menteri Lingkungan Hidup dan Kehutanan RI No. P59/Menlhk/Setjen/kum.1/7/2016 tentang Baku Mutu Lindi bagi Usaha dan/atau Kegiatan Tempat Pemrosesan Akhir Sampah.

Peraturan Pemerintah Republik Indonesia No.82 Tahun 2001 tentang Pengelolaan Kualitas Air dan Pengendalian Pencemaran Air.

Samudro, G and Mangkoedihardjo, S., (2010), Review on BOD, COD, and BOD/COD Ratio: A Triangle Zone for Toxic, Biodegradable and Stable Levels. International Journal of Academic Research, 2(4): 235-239.

Sari, R.N and Afdal. (2017). Karakteristik Air Lindi (Leachate) di Tempat Pembuangan Akhir Sampah Air Dingin Kota Padang. Jurnal Fisika Unand, 6(1): 93-99. 